\title{
Use of Serum Cystatin C in Assessment of Early Deterioration of Renal Function in Type 2 Diabetic Industrial Workers in Port Harcourt, Nigeria
}

\author{
OrluweneChituru Godwill ${ }^{1}$ Nkoyo Ntuen ${ }^{2}$ \\ B.Med. Sci; MBBS; FMCPath MBBS;FMCPath \\ 1. Department of Chemical Pathology, University of Port Harcourt Teaching Hospital, \\ Port Harcourt, Rivers State Nigeria \\ 2. Department of Chemical Pathology, Faculty of Basic Medical Sciences, College of Health Sciences, \\ University of Port Harcourt, Choba, Nigeria.
}

\begin{abstract}
Early detection of deterioration or impairment in renal function is critical in management of diabetic patients. Serum cystatin $C$ may be the most sensitive indicator of glomerular filtration rate (GFR) in a clinical environment.

We compared cystatin $C$ with creatinine, the Cockcroft-Gault $(C-G)$ formular, and the Modification of Diet in Renal Disease (MDRD) equation for the assessment of early decreased renal function in 50 type 2 diabetic patients with and without significant renal impairment [GFR; 8-205 $\left.\mathrm{ml} / \mathrm{min} / 1.73 \mathrm{~m}^{2}\right]$.Relationships of cystatin C, creatinine, and iohexol clearance were linearized using simple regression model and diagnostic efficiency calculated.

In our study population, cystatin $C(P<0.001)$ was better correlated with glomerular filtration rate $(G F R)$ $(r=0.922)$ than were creatinine $(r=743)$, Cockcroft-Gault $(C-G)$ formular $(r=0.755)$ and Modification of Diet in Renal Disease $(M D R D)$ equation $(r=0.818)$. Mean cystatin $C$ concentrations showed step wise statistically significant increases as GFR reduces, allowing very early identification of reduction in renal function. At $90 \mathrm{ml} / \mathrm{min} / 1.73 \mathrm{~m}^{2}$ and $75 \mathrm{ml} / \mathrm{min} / 1.73 \mathrm{~m}^{2}$ cut-points, diagnostic efficiencies of cystatin C $(90 \%$ and $93 \%)$ were better than those of the other variables $(80 \%-84 \%$ and $86 \%-89 \%$, respectively; $P=0.01)$.

All data supported the value of serum cystatin $C$ compared with conventional estimates based on serum creatinine measurement for detecting very early reduction of renal function. Use of cystatin $C$ to measure renal function will make for early detection, prevention, and treatment of diabetic nephropathy in type 2 diabetics.

Keywords: Cystatin C, Early-deterioration-of-renal-function, type 2-diabetes, industrial-workers, Port Harcourt.
\end{abstract}

Submitted date 20 June 2013

Accepted Date: 25 June 2013

\section{Introduction}

Individuals with type 2 diabetes are at risk of impairment of renal function [1,2]. Such individuals with moderate [1] or mildly [2] decreased renal function are at increased risk for chronic renal disease and cardiovascular disease. Untoward outcomes of renal failure can be prevented or delayed by early detection and treatment [3].

Routine measurement of the urine albumin-to-creatinine ratio and estimation of glomerular filtration rate (GFR) are strongly recommended for patients at high risk for kidney failure and cardiovascular disease, such as type 2 diabetic patients [4].

Gold standard procedures for GFR measurement based on the clearance of ${ }^{51} \mathrm{Cr}$-EDTA or iohexol, are impractical in the clinical setting and for larger research studies especially in developing countries of the world. Creatinine alone on the other hand is unsatisfactory to estimate GFR as it will lead to delays in detecting early stages of kidney failure [3]. It is also important to understand that apart from renal function, serum creatinine also depends on creatinine generation, extra-renal elimination and tubular handling [5]. Equations estimating GFR overcomes some of these limitations. Creatinine clearance calculated by the Cockcroft-Gault (C-G) formularoverestimates GFR as renal function declines and tubular secretion increases. The Modification of Diet in Renal Disease (MDRD) equations shows low accuracy at higher GFR [6, 7]. 
Use of Serum Cystatin C in Assessment of Early Deterioration of Renal Function in Type 2 Diabetic

Cystatin C, a cysteine protease inhibitor with a molecular weight of 1300 Daltons has been identified as a new, promising and easily measurable marker for prompt detection of early kidney failure [8,9]. Cystatin $\mathrm{C}$ is produced at a constant rate by nucleated cells and released into the blood stream with a half-life of about 2 hours [10]. Cystatin C is freely filtered and almost completely taken up and degraded, but not secreted, by proximal tubular cells. Several studies have used direct measures of GFR as the gold standard to compare cystatin C with creatinine and creatinine-derived estimates of GFR [11]. Several studies have also been conducted on diabetic patients [12-21] in whom cystatin C seems to out-perform creatinine-based estimations [12,14-18,20,21]. The clinical utility of cystatin still remains uncertain [22].

Using iohexol plasma clearance as the reference GFR, we compared cystatin C with serum creatinine C-G, and MDRD for estimating GFR in industrial workers with type 2 diabetes.

\section{Subjects and methods}

A total of 50 black type 2 diabetic patients were recruited from the metabolic clinic of the Nigerian National Petroleum Corporation Zonal Clinic in Port Harcourt between February, 2009 and December, 2010. The management and Ethical Committee of the health institution approved the study and the study was conducted in compliance with the Helsink, declaration. All the participants gave written informed consent.

Among the type 2 diabetics ( $\mathrm{n}=50), 26 \%$ had Albumin: Creatinine(A/C) ratios within the reference interval, $62 \%$ had microalbuminuria and $12 \%$ had overt nephropathy. Hypertension, defined as blood pressure $>140 / 90 \mathrm{mmHg}$ and/or ongoing treatment occurred in $50 \%$ and $76 \%$ of patients, respectively. All patients with hypertension and/or increased microalbuminuria were on ACE-inhibitors and/or AT1-antagonists. In 75\% of these patients, calcium channel blockers and/or diuretics or other antihypertensives were also employed.

Urinary albumin was measured by a nephelometric immunoassay on the $\mathrm{BN}^{\mathrm{TM}}$ nephelometer (Dade/Behring) in at least 3 first-morning urine samples obtained in a 6-month period. Microalbuminuria was defined as an $\mathrm{A} / \mathrm{C}$ ratio of 2.5 (3.5 in females) to $30 \mathrm{mg} / \mathrm{mmol}$; clinicalnephropathy as an $\mathrm{A} / \mathrm{C}$ ratio $>30 \mathrm{mg} / \mathrm{mmol}$ and/or a serumcreatinine $\geq 133 \mu \mathrm{mol} / \mathrm{L}$ in males or $\geq 115 \mu \mathrm{mol} / \mathrm{L}$ in females.

Serum and urinary creatinine were determined by a fully automated Jaffe kinetic method on a Roche 747 analyzer. Since the serum creatinine assay had not been recalibrated to be traceable to an isotope dilution mass spectrometry reference method [23], the original MDRD equation was employed for estimating GFR: [GFR $\left(\mathrm{ml} / \mathrm{min} / 1.73 \mathrm{~m}^{2}\right)=186 \mathrm{X}$ (plasma creatinine $)(0.011312)^{-1.154} \mathrm{X}(\text { Age })^{-0.203} \mathrm{X}(0.742$ if female $) \mathrm{X}(1.210$ for blacks $\left.)\right]$. We also estimatedGFR by the C-G formular: Creatinine clearance $(\mathrm{mL} / \mathrm{min})=(140-$ Age $($ years $) \mathrm{x}$ weight $(\mathrm{kg}) / 0.814$ $\mathrm{x}$ plasma creatinine $(\mu \mathrm{mol} / \mathrm{L}) \mathrm{x}(0.85$ in females $)[3]$.

Serum cystatin $\mathrm{C}$ was measured by a particle-enhanced nephelometric immunoassay (N Latex Cystatin $\mathrm{C}$, Dade Behring Diagnostics) on the BNII nephelometer.

GFR was assessed by the iohexol plasma clearance (iGFR) method [24]. An intravenous bolus of $5 \mathrm{~mL}$ of iohexol (Ominipaque 300; Nycomed) was injected. Blood specimens were drawn at 5, 15, 60, 180, 240, and 300 min. if creatinine was $>176 \mu \mathrm{mol} / \mathrm{L}$, specimens were withdrawn also at $360 \mathrm{~min}$ and $420 \mathrm{~min}$ after injection; if creatinine was $>440 \mu \mathrm{mol} / \mathrm{L}$ a further specimen was taken at the 1440th minute.

\section{Statistical Methods}

Results are represented as mean (SD) or median (range). To check Gaussian distribution, data were evaluated by the Kolgomorov-Smirnov test, taking $\mathrm{P}<0.001$ as significant. Cystatin $\mathrm{C}$ and creatinine were found not to have a gaussisan distribution; their logarithms were employed in all statistical treatments. Differences in continuous variables were investigated by the one-way ANOVA followed by the Scheffè test and the unpaired student $\mathrm{t}$-test. Fisher exact test and $\mathrm{X}^{2}$ test were employed to analyze contingency tables. The limit of significance was $\mathrm{P}<0.05$. Reciprocals of cystatin $\mathrm{C}$ and creatinine allowed the linearization of the curvilinear relationship between iGFR and each serum marker.

Correlations were investigated by the simple linear regression and by calculating the coefficient of regression. To assess the diagnostic value of each marker, non-parametric ROC curves were generated by plotting the sensitivity vs 1-specificity. Areas under the curves (AUC), 95\% confidence interval (CI), and differences between ROC curves were calculated. In creating ROC curves, we used 3 cut-offs foriGFR: 60, 75 and $90 \mathrm{ml} / \mathrm{min} / 1.73 \mathrm{~m}^{2}$. For each value we obtained the maximum diagnostic efficiency (the proportion of patients correctly classified at each cut-point), the cut-off limits at maximum efficiency, sensitivity and specificity, positive predictive values (PPV) and negative predictive values (NPV).

To investigate variables other than renal function affecting creatinine and cystatin $\mathrm{C}$, multiple regression analyses were performed. 
Use of Serum Cystatin C in Assessment of Early Deterioration of Renal Function in Type 2 Diabetic

\section{Results}

The general characteristics of patients with type 2 diabetes and renal function tests are shown in Table 1 .

Cystatin $\mathrm{C}$ correlated more strongly $(\mathrm{P}=0.005)$ with iGFR $(\mathrm{n}=50, \mathrm{r}=0.922, \mathrm{P}<0.0001)$ than did creatinine $(r=0.743, P<0.0001)$. Furthermore, cystatin $C$ showed better correlation with iGFR $(P<0.05)$ than $C-G$ $(\mathrm{r}=0.755, \mathrm{P}<0.0001)$ and MDRD $(\mathrm{r}=0.818, \mathrm{P}<0.0001)$. These are the correlations found in our type 2 diabetic subjects (Table 2).

Regression was stronger for patients with reduced GFR $\left(<90 \mathrm{ml} / \mathrm{min} / 1.73 \mathrm{~m}^{2}\right)$ than for those with normal GFR. For patients with reduced GFR, all parameters had approximately the same correlation value with GFR (p < $0.0001)$. For patients with normal GFR, cystatin $\mathrm{C}$ had a higher correlation value $(\mathrm{r}=0.67, \mathrm{P}<0.001)$ than all the other variables (Table 3).

We divided GFR values into 6 categories $[<45, \quad 45-59.9, \quad 60-74.9, \quad 75-89.9, \quad 90-119.9$ and $\geq 120 \mathrm{ml} / \mathrm{min} / 1.73 \mathrm{~m}^{2}$ ], incorporating the guidelines of the US National Kidney Foundation [3]. Distributions of sexes $\left(\mathrm{X}^{2}=5.39, \mathrm{P}=0.380\right)$ were similar in the 6 categories that did not differ in age $(\mathrm{P}=0.471)$ and only slightly in BMI $(\mathrm{P}=0.009)$, because of a lower BMI in patients with $\mathrm{GFR}<45 \mathrm{ml} / \mathrm{min} / 1.73 \mathrm{~m}^{2}$. However, patients with iGFR $>120 \mathrm{ml} / \mathrm{min} / 1.73 \mathrm{~m}^{2}$ were younger $(\mathrm{p}<0.005)$ and more frequently males $(\mathrm{P}=0.025)$.

In the study patient population (Fig.1), decreasing iGFR was associated with increasing cystatin C, increasing creatinine, and decreasing GFR as estimated by both C-G and MDRD. Among iGFR categories, however, a step-by-step statistically significant change in the mean values was observed only forcystatin $\mathrm{C}$ (Fig 1A). Thuscystatin C not only reveals early decreases in GFR $\left(75-90 \mathrm{ml} / \mathrm{min} / 1.73 \mathrm{~m}^{2}\right)$ but also reflects changes within the reference interval $\left(>90 \mathrm{ml} / \mathrm{min} / 1.73 \mathrm{~m}^{2}\right.$ ). Creatinine(Fig.1B) and C-G (Fig.1C) did not reflect early decreases in renal function (differences in C-G within the GFR referenceinterval disappeared when corrected for age and sex) but showed significant decreases only wheniGFR was $75 \mathrm{ml} / \mathrm{min} / 1.73 \mathrm{~m}^{2}$ or lower. Use of MDRD seems to reflect changes even within the reference range (Fig.1D), but renal function is estimated with low precision in individuals with a higher GFR. Indeed, the bias between MDRD and iGFR tends to increase for GFR values <45 and $>90 \mathrm{ml} / \mathrm{min} / 1.73 \mathrm{~m}^{2}$. In particular, MDRD underestimated GFR by $19 \%$ and $29 \%$ in patients' with iGFR values of $90-119.9$ and $\geq 120 \mathrm{ml} / \mathrm{min} / 1.73 \mathrm{~m}^{2}$, respectively (Fig.2).

ROC plots for cystatin C andcreatinine (Table 4) demonstrated that the AUC of cystatin C was greater than that ofcreatinine at a cutoff level of $90(\mathrm{P}=0.002)$ and $75 \mathrm{ml} / \mathrm{min} / 1.73 \mathrm{~m}^{2}(\mathrm{p}=0.0015)$, but not at a cutoff threshold of $60 \mathrm{ml} / \mathrm{min} / 1.73 \mathrm{~m}^{2}(\mathrm{P}=0.351)$.

Likewise, AUC for cystain $\mathrm{C}$ was greater than those for $\mathrm{C}-\mathrm{G}$ and MDRD at the cutoff levels of $90(\mathrm{P}=$ 0.0006 and $\mathrm{P}=0.005$, respectively) and $75 \mathrm{ml} / \mathrm{min} / 1.73 \mathrm{~m}^{2}(\mathrm{P}=0.0043$ and $\mathrm{P}=0.0040$, respectively), but not at the cutoff of $60 \mathrm{ml} / \mathrm{min} / 1.73 \mathrm{~m}^{2}(\mathrm{P}=0.190$ and $\mathrm{P}=0.458)$.

At the cut-point of $90 \mathrm{ml} / \mathrm{min} / 1.73 \mathrm{~m}^{2}$, the maximum diagnosticefficiency of cystatin $\mathrm{C}(90 \%)$ was higher than those of creatinine $(84 \%, \mathrm{P}=0.04), \mathrm{C}-\mathrm{G}(80 \%, \mathrm{P}=0.004)$ and $\mathrm{MDRD}(82 \%, \mathrm{P}=0.02)$.

The cutoff limit of $0.98 \mathrm{mg} / \mathrm{L}$ for cystatin C corresponds to a PPV of $91 \%$ and NPV of $85 \%$. The respective features for the cutoff limit of $98 \mu \mathrm{mol} / \mathrm{L}$ for creatinine were PPV $83 \%$ and NPV $77 \%$. At the cutoff point of $75 \mathrm{ml} / \mathrm{min} / 1.73 \mathrm{~m}^{2}$, the maximum diagnostic efficiency was $93 \%$ for cystatin $\mathrm{C}, 89 \%(\mathrm{P}=0.01)$ for creatinine, $86 \%$ for $\mathrm{C}-\mathrm{G}$ and $88 \%$ for MDRD ( $\mathrm{P}=0.04)$. The cutoff limit of $1.13 \mathrm{mg} / \mathrm{L}$ for cystatin $\mathrm{C}$ corresponds to a PPV of $95 \%$ and NPV of $93 \%$. The respective features for the cutoff limit of $110 \mu \mathrm{mol} / \mathrm{L}$ for creatinine are PPV $83 \%$ and NPV $89 \%$. No differences between the parameters estimating GFR were observed when the cutoff was at $60 \mathrm{ml} / \mathrm{min} / 1.73 \mathrm{~m}^{2}$ (Table 4).

In patients with normal GFR (> 90ml/min $\left./ 1.73 \mathrm{~m}^{2}\right)$, mean $(\mathrm{SD})$ creatinine was higher $(\mathrm{P}>0.05)$ in males than in females (83 (12) $\mu$ molLVs $72(11) \mu \mathrm{mol} / \mathrm{L}$, respectively) but no difference $(\mathrm{P}=0.14)$ were observed for cystatin C (0.74 (0.13) Vs $0.72(0.06) \mathrm{mg} / \mathrm{L})$. In patients with decreased GFR, no sex differences were observed for either creatinine or cystatin $\mathrm{C}$.

Age was weakly related to creatinine in our type 2diabetic patients $(r=0.23, \mathrm{P}=0.008)$ but not in patients with normal GFR. Age was also related to cystatin $\mathrm{C}$ in type 2 diabetic patients used in our study $(\mathrm{r}=0.48, \mathrm{P}<$ 0.001). This correlation persisted in patients with normal GFR $(\mathrm{r}=0.57, \mathrm{P}<0.001)$.

An inverse relationship was observed between BMI and creatinine $(r=-0.15, \mathrm{P}=0.003)$. This correlation was also present in those with normal GFR $(r=-0.19, \mathrm{P}=0.01)$ and therefore was not driven by the lower BMI of patients with severe renal impairment. A correlation between BMI and cystatin $\mathrm{C}(\mathrm{r}=-0.18, \mathrm{P}=0.004)$ was also observed, but was lost in patients with normal GFR.

Multiple regression analysis indicated that for the whole study population, extra-renal factors (including hypertension and smoking) affected both creatinine (sex, BMI) and cystatin C (Age, hypertension) independently of 
Use of Serum Cystatin C in Assessment of Early Deterioration of Renal Function in Type 2 Diabetic

renal function. Half of the explained variation of creatinine was attributable to extra-renal factors, whereas extrarenal factors account only for approximately a quarter of explained variation of cystatin C.

\section{Discussion}

It has been reported extensively that the production of cystatin $\mathrm{C}$ is unaffected by age, height, weight, muscle and sex [10].In our study, cystatin C, unlike creatinine, was unaffected by sex and Body Mass index (BMI), but was correlated with age independently of GFR. These effects, though negligible when the entire range of renal function was considered, became significant in patients with normal GFR. Compared to creatinine, the proportion of variations in cystatin $\mathrm{C}$ attributable to extra renal factors is considerably lower (57\% vs $24 \%$ ).

Other studies involving larger study population $[25,26]$ with consistent result found that cystatin $\mathrm{C}$ is influenced by many variables (age, sex, body mass, smoking, hypertension, coronary heart disease, C-reactive protein)other than renal function alone, even after adjustment for kidney function .The studies excluded patients with moderate and severe renal failure and in all cystatin $\mathrm{C}$ was highly correlated with age $(\mathrm{r}=0.40)$.

Creatinine tends to be increased in patients with hypothyroidism and decreased in those with hyperthyroidism. The production of cystatin $\mathrm{C}$ is influenced by thyroid hormone such that concentration of cystatin $\mathrm{C}$ are low in hypothyroidism, even in mild forms [27,28] and increased in hyperthyroidism[27]. It has been reported that thyroid dysfunction is increased in frequency in the diabetic population [29]. Thyroid status was well known in all our study type 2 diabetic patients and patients who were not euthyroid were excluded.

Even if non-renal influences, including polymorphisms in the promoter and exon 1 of the cystatin $\mathrm{C}$ gene [30,31], make cystatin C not completely reliable as a measure of renal function, most studies have found cystatin C to be a better marker of GFR than creatinine. In a recent meta-analysis [9], approximations of GFR performed with cystatin $\mathrm{C}$ compared with creatinine had higher correlation coefficients $(0.816 \mathrm{vs} 0.742 ; \mathrm{P}<0.001)$ and ROC- AUC (0.926 vs $0.837 ; \mathrm{P}<0.001)$.

In our study, using 4 methods of evaluation (correlations with GFR, mean values of each variable in patients stratified by GFR values, ROC curves, and diagnostic efficiency) we showed that cystatin C is more sensitive for detecting early renal function impairment than creatinine and creatinine derived formulas.

The correlation of cystatin $C$ with GFR was stronger than the correlation with creatinine, C-G, or MDRD. As earlier reported in type 2 diabetes [14], and also observed in our study, the correlations between GFR and creatinine or cystatin $\mathrm{C}$ were higher in patients with decreased than in those with normal GFR.

In patients with normal renal function the relationship between cystain C and GFR was stronger than between GFR and the other 3 variables. This different behavior is due not only to the wider range of GFR values of patients with reduced renal function but also to the role played by different pathophysiological factors. In patients with reduced GFR, both cystatin $\mathrm{C}$ and creatinine are strongly and comparably influenced by renal impairment. Furthermore, cystatin $\mathrm{C}$ has been reported to have significant non-renal clearance that, as for creatinine, has a relatively greater impact in patients with severe renal failure [32]. Thus cystatin $\mathrm{C}$ and creatinine are stronglyinfluenced by common factors and closely correlated in patients with reduced GFR, whereas the correlation is lower in patients with normal GFR as a consequence of the different weight of different factors that affect serum concentrations. The lower variance and the relatively greater importance of extra renal covariates in affecting serumcreatinine largely account for its insensitivity for detecting small decreases in GFR, in the so-called creatinine-blind GFR area.

Comparison of the mean values of the 4 variables in groups with different GFRs clearly revealed the performance of cystatin $\mathrm{C}$ when we focused on differences within the creatinine-blind GFR range, when creatinine and $\mathrm{C}-\mathrm{G}$ are normal or do not change significantly despite declining renal function. With MDRD calculations, it seems possible to detect changes in renal function even within the GFR references range, but at the price of an unacceptable underestimation of GFR.

The diagnostic efficiency of cystatin C, as shown by the AUCs of the ROC curves is higher than those of the other indexes. TheGFR reference threshold chosen, below which GFR is defined as impaired, influences the diagnostic efficiency of the methods under investigation. At both 90 and $75 \mathrm{ml} / \mathrm{min} / 1.73 \mathrm{~m}^{2}$ GFR, efficiency was higher for cystatin $\mathrm{C}$ and comparable for the other parameters. The lower the GFR limit chosen, the more the ROC curves for MDRD, C-G, creatinine, and cystatin C approach each other. Our ROC curvesconfirmed that cystatin C is a better diagnostic tool than creatinine, $\mathrm{C}-\mathrm{G}$, and MDRD both for identifying diabetic patients with normal (>90) or near normal $\left(>75 \mathrm{ml} / \mathrm{min} / 1.73 \mathrm{~m}^{2}\right)$ GFR and for detecting patients with early $(<75)$ or very early $\left(<90 \mathrm{ml} / \mathrm{min} / 1.73 \mathrm{~m}^{2}\right)$ impairment of GFR.

Previous studies on the role of cystatinCin detecting early renal failure in diabetic patients were contradicting. Some authors showed thatcystatin $\mathrm{C}$ was more effective than creatinine in detecting initial reduction of GFR in type $2[12,14,17,20,21]$ as well as in type 1 diabetes $[15,21]$. Two further studies, which did 
notemploy a gold standard method for GFR, confirmed that cystatin C better differentiates GFR values among type $1[18]$ and type $2[16,18]$ diabetic patients. Two studies [13, 19], on the other hand, showed that cystatinC is not more sensitive than creatinine for detecting early renal failure. Such discrepancies may be attributable at least in part tointraassay variations for creatinine and cystatin $\mathrm{C}$ measurements related to differences in assay techniques. We employed a nephelometric assay for cystatin C, a method claimed to perform with higher accuracy [33]. Discrepancies may also arise from different and often arbitrarily chosen cut-points for the definition of abnormalities in renal function. In our study, the cut-points for GFR stratification incorporate the guidelines of the US National Kidney Foundation [3].

Some studies have successfully investigated the possibility of introducing cystatin C-based formulas without anthropometric variables to replace creatinine-based equations in predicting GFR [34].

\section{Conclusion}

Although multiple factors in addition to renal function may influence cystatin $\mathrm{C}$, our study provides convincing evidence that cystatin $\mathrm{C}$ may be more useful for detecting early renal impairment in type 2 diabetic patients than are creatinine and commonly employed creatinine-derived formulas. These results are remarkable in the light of recent reports suggesting that cystatin $\mathrm{C}$ is a useful indicator of risk for cardiovascular events, peripheral arterial disease, heart failure and death $[35,36]$. Detection of early renal impairment using cystatin $C$ would be very useful in the management of type 2 diabetics as it will facilitate early institution of appropriate therapeuticmeasures that will ensure a better treatment outcome in this group of patients.

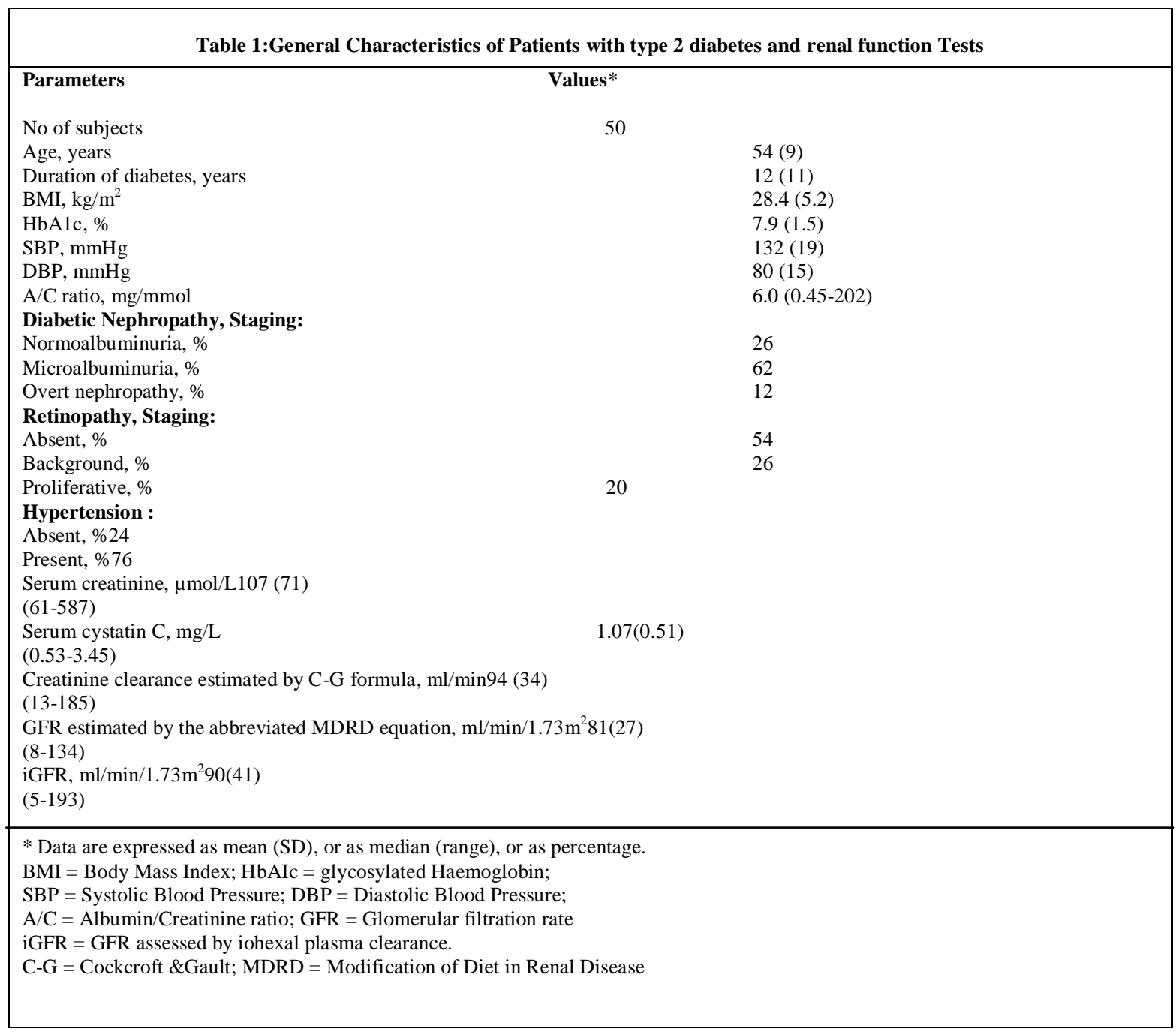


Table 2: Correlation Between iGFR and reciprocal of serum cystatin $C$, reciprocal of serum creatinine, creatinine clearance calculated by the C-G formula, and GFR estimated by the abbreviated MDRD equation respectively in type 2 diabetic patients (n =50).

Parameters

*1/Serum cystatin $\mathrm{C}, \mathrm{mg} / \mathrm{L}$

* $1 /$ Serum creatinine, $\mu \mathrm{mol} / \mathrm{L}$

Creatinine clearance calculated by the $\mathrm{C}-\mathrm{G}$ formula, $\mathrm{ml} / \mathrm{min}$

GFR estimated by the abbreviated MDRD equation, $\mathrm{mL} / \mathrm{min} / 1.73 \mathrm{~m}^{2}$

Comparison between the 4 correlations
*Cystatin $\mathrm{C}$ and creatinine values were log-transformed

$+\mathrm{P}=0.002$ vs correlation coefficient of $1 /$ creatinine, $\mathrm{P}=0.005$ vs correlation

coefficient of $\mathrm{C}-\mathrm{G}, \mathrm{P}=0.213$ vs correlation coefficient of MDRD.

\begin{tabular}{|c|c|c|}
\hline \multirow[t]{2}{*}{ Parameter } & \multicolumn{2}{|c|}{ Type 2 Diabetes $(n=50)$} \\
\hline & $\begin{array}{l}\text { Reduced GFR } \\
\quad<90(\mathrm{n}=36)\end{array}$ & $\begin{array}{l}\text { Normal GFR } \\
>90(n=14)\end{array}$ \\
\hline *1/Serum cystatin $\mathrm{C}, \mathrm{mg} / \mathrm{L}$ & $\begin{aligned} & r=0.756 \\
&(\mathrm{P}<0.0001)\end{aligned}$ & $\begin{array}{l}r=0.670^{+} \\
(P<0.01)\end{array}$ \\
\hline 1/Serum creatinine, $\mu \mathrm{mol} / \mathrm{L}$ & $\begin{array}{l}r=0.801 \\
(\mathrm{P}<0.0001)\end{array}$ & $\begin{array}{l}r=0.300 \\
(\mathrm{P}<0.01)\end{array}$ \\
\hline $\begin{array}{l}\text { Creatinine clearance calculated by the } \\
\text { C-G formula, } \mathrm{mL} / \mathrm{min}\end{array}$ & $\begin{array}{l}r=0.751 \\
(\mathrm{P}<0.0001)\end{array}$ & $\begin{array}{l}r=0.380 \\
(\mathrm{P}<0.01)\end{array}$ \\
\hline $\begin{array}{l}\text { GFR estimated by the abbreviated } \\
\text { MDRD equation, } \mathrm{ml} / \mathrm{min} / 1.73 \mathrm{~m}^{2}\end{array}$ & $\begin{array}{l}r=0.813 \\
(\mathrm{P}<0.0001)\end{array}$ & $\begin{array}{l}r=0.445 \\
(\mathrm{P}<0.01)\end{array}$ \\
\hline Comparison between the 4 correlations & NS & 0.0105 \\
\hline \multicolumn{3}{|l|}{$\begin{array}{l}\text { *Cystatin } \mathrm{C} \text { and creatinine values were } \\
\text { log-transformed. } \\
+\mathrm{P}=0.0007 \text { vs correlation coefficient } \\
\text { of } 1 / \text { creatinine, } \mathrm{P}=0.005 \mathrm{Vs} \\
\text { coefficient of } \mathrm{C}-\mathrm{G}, \mathrm{P}=0.017 \mathrm{vs} \\
\text { coefficient of MDRD. }\end{array}$} \\
\hline
\end{tabular}

Table 3: Correlations between iGFR and reciprocal of serum cystatin $C$, reciprocal
of serum creatinine, creatinine clearance calculated by the $C-G$ formula, and GFR he abbreviated MDRD equation, respectively in type 2 diabetes Type 2 Diabetes $(n=50)$

$\mathrm{r}=0.922^{+}(\mathrm{P}<0.0001)$

$\mathrm{r}=0.743(\mathrm{P}<0.0001)$

$\mathrm{r}=0.755(\mathrm{P}<0.0001)$

$\mathrm{r}=0.818(\mathrm{P}<0.0001)$

0.01 
Table 4:ROC analysis for serum cystatin C, creatinine clearance calculated by the C-G formula and GFR estimated by the abbreviated MDRD equation in the type 2 diabetic patients

\begin{tabular}{|c|c|c|c|c|c|c|c|c|}
\hline Parameter & ROC Area & $95 \% \mathrm{CI}$ & $\begin{array}{l}\text { Diagnostic } \\
\text { efficiency, } \%\end{array}$ & $\begin{array}{l}\text { Cutoff } \\
\text { point, } \%\end{array}$ & $\begin{array}{l}\text { Sensitivity, } \\
\% \%\end{array}$ & $\begin{array}{l}\text { Specificity } \\
0 \%\end{array}$ & PPV $\%$ & NPV $\%$ \\
\hline \multicolumn{9}{|c|}{ iGER cutoff level: $90 \mathrm{ml} / \mathrm{min} / 1.73 \mathrm{~m}^{2}$} \\
\hline Cystatin C & 0.92 & $0.89-0.98$ & 90 & 0.98 & 83 & 94 & 91 & 85 \\
\hline Creatinine & 0.88 & $0.82-0.92$ & 84 & 1.11 & 73 & 91 & 83 & 77 \\
\hline $\mathrm{C}-\mathrm{G}$ & 0.84 & $0.78-0.87$ & 80 & 82 & 75 & 81 & 78 & 76 \\
\hline \multirow[t]{4}{*}{ MDRD } & 0.89 & $0.84-0.93$ & 82 & 69 & 71 & 88 & 83 & 75 \\
\hline & $\mathrm{P}=0.002 \mathrm{x}$ creatinine & \multicolumn{2}{|c|}{$\mathrm{X}^{2}=11.1$} & & & & & \\
\hline & $\mathrm{P}=0.0006 \mathrm{\textrm {ga }} \mathrm{C}-\mathrm{G}$ & \multicolumn{2}{|c|}{ 3df } & & & & & \\
\hline & $\mathrm{P}=0.0005 \mathrm{xg} . \mathrm{MDRD}$ & \multicolumn{2}{|c|}{$\mathrm{P}=0.01$} & & & & & \\
\hline \multicolumn{9}{|c|}{ iGER cut off level: $75 \mathrm{ml} / \mathrm{min} / 1.73 \mathrm{~m}^{2}$} \\
\hline Cystatin C & 0.98 & $0.93-0.99$ & 93 & 1.13 & 80 & 97 & 95 & 93 \\
\hline Creatinine & 0.90 & $0.86-0.95$ & 89 & 1.25 & 72 & 93 & 83 & 89 \\
\hline $\mathrm{C}-\mathrm{G}$ & 0.90 & $0.85-0.95$ & 86 & 70 & 71 & 94 & 84 & 89 \\
\hline \multirow[t]{4}{*}{ MDRD } & 0.92 & $0.87-0.96$ & 88 & 61 & 73 & 94 & 86 & 90 \\
\hline & $\mathrm{P}=0.0015 \mathrm{ma}$ creatinine & \multicolumn{2}{|c|}{$\mathrm{X}^{2}=11.1$} & & & & & \\
\hline & $P=0.0043 \mathrm{ma}-\mathrm{G}$ & \multicolumn{2}{|c|}{$3 \mathrm{df}$} & & & & & \\
\hline & $\mathrm{P}=0.0044 \mathrm{\textrm {g }} . \mathrm{MDRD}$ & \multicolumn{2}{|l|}{$\mathrm{P}=0.01$} & & & & & \\
\hline \multicolumn{9}{|c|}{ iG $\mathrm{FR}$ cut off level: $60 \mathrm{ml} / \mathrm{min} / 1.73 \mathrm{~m}^{2}$} \\
\hline Cystatin C & 0.98 & $0.93-0.99$ & 91 & 1.23 & 77 & 97 & 89 & 93 \\
\hline Creatinine & 0.94 & $0.91-0.98$ & 90 & 1.40 & 72 & 97 & 88 & 91 \\
\hline$C-G$ & 0.93 & $0.89-0.97$ & 89 & 65 & 78 & 94 & 80 & 92 \\
\hline \multirow[t]{4}{*}{ MDRD } & 0.95 & $0.92-0.99$ & 90 & 55 & 78 & 97 & 88 & 93 \\
\hline & $\mathrm{P}=0.351$ ga creatinine & \multicolumn{2}{|c|}{$\mathrm{X}^{2}=1.02$} & & & & & \\
\hline & $\mathrm{P}=0.190 \mathrm{xa} \mathrm{C}-\mathrm{G}$ & \multicolumn{2}{|c|}{$3 \mathrm{df}$} & & & & & \\
\hline & $\mathrm{P}=0.458 \mathrm{MB}, \mathrm{MDRD}$ & \multicolumn{2}{|c|}{$\mathrm{P}=0.80$} & & & & & \\
\hline
\end{tabular}

Cystatin $\mathrm{C}$ expressed in $\mathrm{mg} / \mathrm{L}$; Creatinine expressed in umol/ $\mathrm{L} ; \mathrm{C}-\mathrm{G}$ expressed in $\mathrm{ml} / \mathrm{min} ; \mathrm{MDRD}$ expressed in $\mathrm{ml} / \mathrm{min} / 1.73 \mathrm{~m}^{2}$

Cystatin and creatinine values were log-transformed before RIC anslysis. Bold font indicates the variables for which statistical analysis was performed.
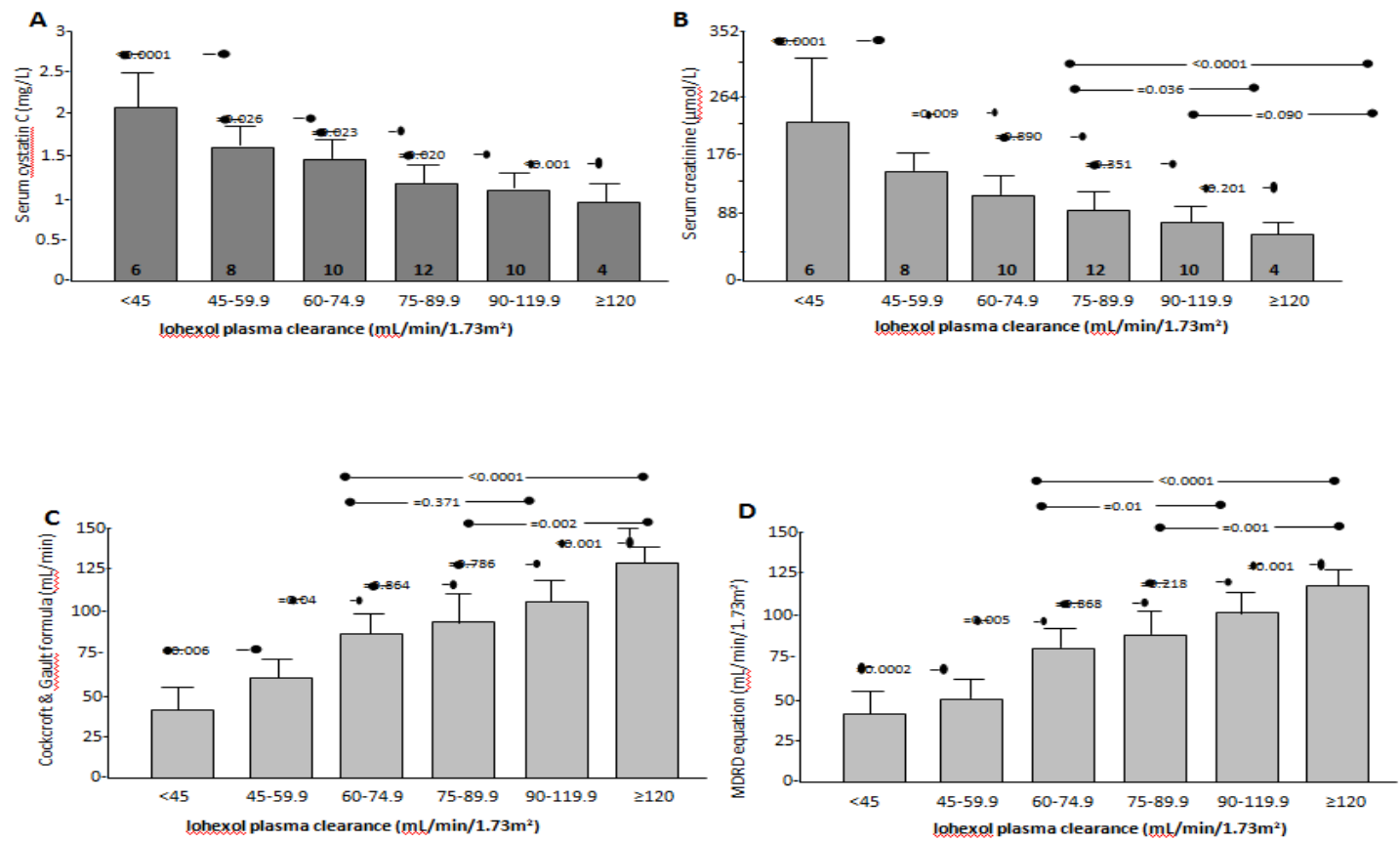

Fig.1. Endogenous serum variables of renal function: $(\boldsymbol{A})$ serum cystatinC; $(\boldsymbol{B})$ serum creatinine; and estimated GFR from prediction equation $(\boldsymbol{C})$, C-G formula; $(\boldsymbol{D})$, MDRD equation; according to GFR assessed by iohexol plasma clearance.

For each variable, one-way ANOVA gives a $P$ value $<0.0001$. Both cystatin $\mathrm{C}$ and creatinine were 1 og-tranformed before analysis $(p$ values reported in the 4 panels were obtained by the Scheffe' test) 


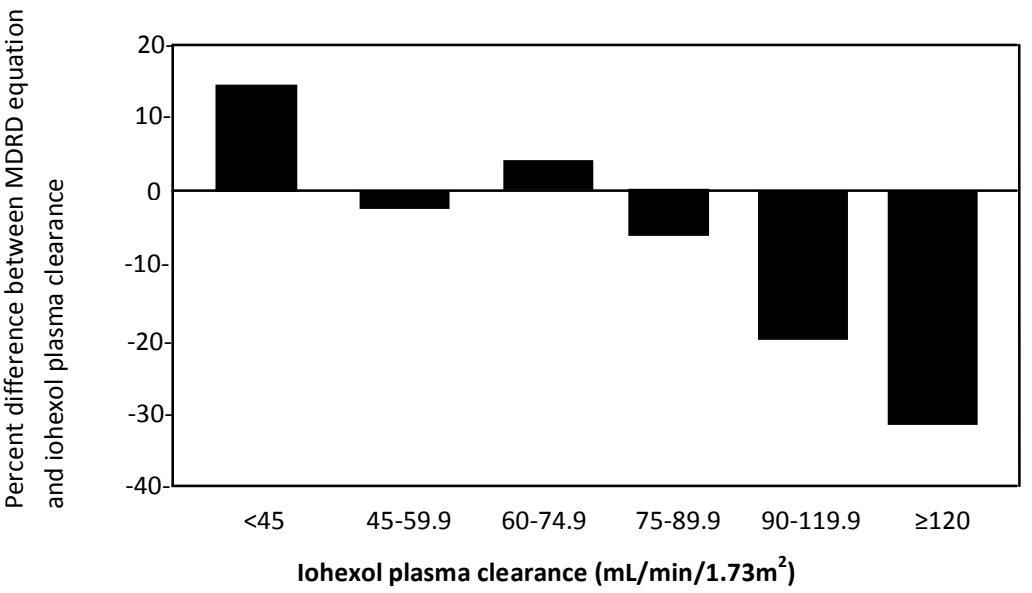

Fig.2. Percentage difference between GFR estimated by the MDRD equation and the iohexol plasma clearance to GFR assessed by iohexol plasma clearance.

\section{References}

[1]. Go AS, Chertow GM, Fan D, McCulloch CE, Hsu CY. Chronic kidney disease and the risks of death, cardiovascular events, and hospitalization. N Engl J Med 351, 2004, 1296-1305.

[2]. Anavekar NS, McMurray JJ, Velazquez EJ, Solomon SD, Kober L, Rouleau JL, et al. Relation between renal dysfunction and cardiovascular outcomes after myocardial infarction. N Engl J Med 351, 2004, 1285-1295.

[3]. Levey AS, Coresh J, Balk E, Kausz AT, Levin A, Steffes MW, et al. National Kidney Foundation. National Kidney Foundation practice guidelines for chronic kidney disease: evaluation, classification, and stratification. Ann Intern Med 139, 2003, 137-147.

[4]. Sarnak MJ, Levey AS, Schoolwerth AC, Coresh J, Colleton B, Hamm LL, et al. American Heart Association Councils on Kidney in cardiovascular Disease, High Blood Pressure Research, Clinical Cardiology, and Epidemiology and Prevention. Kidney disease as a risk factor for development of cardiovascular disease: a statement from the American Heart Association Councils on kidney in cardiovascular Disease, High Blood Pressure Research, Clinical cardiology, and Epidemiology and Prevention. Circulation 108, 2003, $2154-2169$.

[5] Stevens LA, Levey AS. Measurement of kidney function.Med Clin North Am 89, 2005, 457-473.

[6] Levey AS, Bosch JP, Lewis JB, Greene T, Rogers N, Roth D. A more accurate method to estimate glomerular filtration rate from serum creatinine: a new prediction equation. Modification of Diet in Renal Disease Study Group.Ann Intern Med 130, 1999; 461-470.

[7] Rule AD, Larson TS, Bergstralh EJ, Slezak JM, Jacobsen SJ, Cosio FG. Using serum creatinine to estimate glomerular filtration rate: accuracy in good health and in chronic kidney disease.Ann Intern Med 141, 2004, 929-937.

[8] Levin A. Cystatin C, serum creatinine, and estimates of kidney function: searching for better measures of kidney function and cardiovascular risk. Ann Intern Med 142, 2005, 586-588.

[9] Dharnidharka VR, Kwon C, Stevens G. Serum cystatin C is superior to serum creatinine as a marker of kidney function: a meta-analysis. Am J Kidney Dis 40, 2002, 221-226.

[10] Filler G, Bokenkamp A, Hofmann W, Le Bricon T, Martinez-Bru C, Grubb A. Cystatin C as a marker of GFR-history, indications, and future research. ClinBiochem 38, 2005, 1-8.

[11] Mussap M, Plebani M. Biochemistry and clinical role of human cystatin C. Crit Rev Clin Lab Sci 41, 2004, 467-550.

[12] Harmoinen AP, Kouri TT, Wirta OR, Lehtimaki TJ, Rantalaiho V, Turjanmaa VM, et al. Evaluation of plasma cystatin C as a marker for glomerular filtration rate in patients with type 2 diabetes. ClinNephrol 52, 1999, 363-370.

[13] Oddoze C, Morange S, Portugal H, Berland Y, Dussol B. Cystatin C is not more sensitive than creatinine for detecting early renal impairment in patients with diabetes. Am J Kidney Dis 38, 2001, 310-316.

[14] Mussap M, DallaVestra M, Fioretto P, Saller A, Varagnolo M, Nosadini R, et al. Cystatin C is a more sensitive marker than creatinine for the estimation of GFR in type 2 diabetic patients. Kidney Int 61, 2000, 1453-1461.

[15] Tan GD, Lewis AV, James TJ, Altmann P, Taylor RP, Levy JC. Clinical usefulness of cystatin C for the estimation of glomerular filtration rate in type 1 diabetes: reproducibility and accuracy compared with standard measures and iohexol clearance. Diabetes Care 25, 2002, 2004-2009.

[16] Mojiminiyi OA, Abdella N. Evaluation of cystatin C and $\beta-2$ microglobulin as markers of renal function in patients with type 2 diabetes mellitus. J Diabetes Complications 17, 2003, 160-168.

[17] Hoek FJ, Kemperman FA, Krediet Rt. A comparison between cystatin C, plasma creatinine and the Cockcroft and Gaultformula for the estimation of glomerular filtration rate. Nephrol Dial Transplant 18, 2003, 2024-2031.

[18] Buysschaert M, Joudi I, Wallemacq P, Hermans MP. Comparative performance of serum cystatin-C versus serum creatinine in diabetic subjects.Diabetes Metab 29, 2003, 377-383.

[19] Perlemoine C, Beauvieux MC, Rigalleau V, Baillet L, Barthes N, Derache P, et al. Interest of cystatin C in screening diabetic patients for early impairment of renal function. Metabolism 52, 2003, 1258-1264.

[20] Xia LH, Bing XG, An XT. Serum cystatin C assay for the detection of early renal impairment in diabetic patients. J Clin Lab Anal 18 , 2004, 31-35. 
[21] Christensson AG, Grubb, AO, Nilsson JA, Norrgren K, Sterner G, Sundkvist G. Serum cystatin C advantageous compared with serumcreatinine in the detection of mild but not severe diabetic nephropathy. J Intern Med 256, 2004, 510-518.

[22] Curhan G. Cystatin C: a marker of renal function or something more? ClinChem 51, 2005, 293-294.

[23] Myers GL, Miller WG, Coresh J, Fleming J, Greenberg N, Greene T, et al. National Kidney Disease Education Program Laboratory Working Group. Recommendations for improving serum creatinine measurement: a report from the Laboratory Working Group of the National Kidney Disease Education Program. ClinChem 52, 2006, 5-18.

[24] Pucci L, Brandinelli S, Pilo M, Nannipieri M, Navalesi R, Penno G. Iohexol as a marker of glomerular filtration rate in patients with diabetes: comparison of multiple and simplified sampling protocols. Diabet Med 18, 2001, 116-120.

[25] Knight EL, Verhave JC, Spiegelman D, Hillege HL, de Zeeuw D, Curhan GC, et al. Factors influencing serum cystatin C levels other than renal function and the impact on renal function measurement. Kidney Int 65, 2004, 1416-1421.

[26] Wasen E, Suominen P, Isoaho R, Mattila K, Virtanen A, Kivela SL, et al. Serum cystatin C as a marker of kidney dysfunction in an elderly population. ClinChem 48, 2002, 1138-1140.

[27] Manetti L. Pardini E, Genovesi M, Campomori A, Grasso L, Morselli LL, et al. Thyroid function differently affects serum cystatin C and creatinine concentration. J Endocrinol Invest 28, 2005, 346-349.

[28] Wiesli P, Schwegler B, Spinas GA, Schmid C. Serum cystatin C is sensitive to small changes in thyroid function. ClinChimActa 338, 2003, 87-90.

[29] Perros P, McCrimmon RJ, Shaw G, Frier BM. Frequency of thyroid dysfunction in diabetic patients: value of annual screening. Diabet Med 12, 1995, 622-627.

[30] Eriksson P, Deguchi H, Samnegard A, Lundman P, Boquist S, Tornvall P, et al. Human evidence that the cystatin C gene is implicated in focal progression of coronary artery disease. ArteriosclerThrombVascBiol 24, 2004, 551-557.

[31] Loew M, Hoffman MM, Koenig W, Brenner H, Rothenbacher D. Genotype and plasma concentration of cystatin C in patients with coronary heart disease and risk for secondary cardiovascular events. ArteriosclerThrombVascBiol 25, 2005, 1470-1474.

[32] Sjostrom P, Tidman M, Jones I. Determination of the production rate and non-renal clearance of cystatin C and estimation of the glomerular filtration rate from the serum concentration of cystatin C in humans. Scand J Clin Lab Invest 65, 2005, 111-124.

[33] Priem F, Althaus H, Jung K, Sinha P. Beta-trace protein is not better than cystatin C as an indicator of reduced glomerular filtration rate. ClinChem 47, 2001, 2181.

[34] Grubb A, Nyman U, Bjork J, Lindstrom V, Rippe B, Sterner G, et al. Simple cystatin C-based prediction equations for glomerular filtration rate compared with the modification of diet in renal disease prediction equation for adults and the Schwartz and the CounahanBarratt prediction equations for children. ClinChem 51, 2005, 1420-1431.

[35] Shlipak MG, Sarnak MJ, Katz R, Fried LF, Seliger SL, Newman AB, et al. Cystatin C and the risk of death and cardiovascular events among elderly persons. $N$ Engl J Med 352, 2005, 2049-2060.

[36] Shlipak MG, Katz R, Fried LF, Jenny NS, Stehman-Breen CO, Newman AB, et al. Cystatin-C and mortality in elderly persons with heart failure. J Am CollCardiol 45, 2005, 268-271. 